\title{
Supply Chain Management and Offshoring in the US
}

\author{
Kouassi Desire Kossonou \\ University of Central Arkansas \\ Mark McMurtrey \\ University of Central Arkansas
}

\begin{abstract}
In this day and age marked by globalization and the need for firms and managers to get tasks and services done at the lowest possible cost, offshoring jobs in the supply chain has become common practice in companies operating in many countries around the world. Offshoring is a controversial issue, especially in the US as illustrated by the debate between individuals advocating the adverse effects of the offshoring of US jobs and the proponents of its benefits. This does raise several questions, some of which are: What are the causes of offshoring? What impact did Covid-19 have on offshoring and on the supply chain? What are the advantages and disadvantages of offshoring on supply chains of firms in general and particularly in the US? Considering the previous questions, should firms in the US continue to offshore jobs or should they stop doing it? This paper will attempt to provide answers to these questions, as well as offer prescriptive analysis regarding the implementation of ideas to address this situation.
\end{abstract}

Keywords: supply chain management, offshoring, globalization, Covid-19

\section{INTRODUCTION}

In this day and age marked by globalization and the need for firms and managers to get tasks and services done at the lowest possible cost, offshoring jobs has become common practice in companies operating in many countries around the world. The supply chain is one of the most important components of the operations of a company. As such, supply chain management (SCM) is a crucial part of the field of operations management. The offshoring of jobs is very important in operations management nowadays. The United States of America is particularly affected by offshoring because many US jobs are offshored every year. It is argued by the Reshoring Initiative that "three to five million manufacturing jobs have been lost to trade/offshoring since 1979." (2017). Megan Eliott (2018) also pointed out that "according to data from the US Department of Labor, more than 125,000 Americans were eligible for job training assistance in 2016 because they lost their job to a worker abroad or were otherwise displaced because of global trade."

Offshoring is a controversial issue, especially in the US as illustrated by the debate between individuals advocating the adverse effects of the offshoring of US jobs and the proponents of its benefits. Other studies also discuss the impact of offshoring on the supply chain. And yet, other studies highlight the impact of Covid-19 on both offshoring and the supply chain in the US. Such a controversial issue, along with the aforementioned studies do raise several questions, some of which are: What is offshoring? What is supply chain management? How important is supply chain management in the US? What are the causes of 
offshoring? What impact did Covid-19 have on offshoring and on the supply chain? What are the advantages and disadvantages of offshoring on supply chains of firms in general and particularly in the US? What are some recommendations that can be made to address the disadvantages, negative effects of, or problems posed by offshoring? Considering the previous questions, should firms in the US continue to offshore jobs or should they stop doing it? The subsequent parts of this paper will attempt to provide answers to these questions.

\section{Definitions and the Importance of Supply Chain Management}

There are many different definitions of offshoring and supply chain management. Some of them will be provided below. According to Dessler (2015), offshoring means having outside vendors or employees abroad supply services that the company's own employees previously did in-house. Brainard and Litan (2005) also referred to services offshoring as the provision of services in off-shore locations. Similar to the two other definitions, the Population Reference Bureau or PRB (2008) described the term offshoring as the movement of jobs and tasks from one country to the other, usually from high-cost countries, such as the United States, to countries where wages are significantly lower. The PRB (2008) also mentioned that the offshoring of manufacturing jobs has been occurring for decades, but that the offshoring of service-sector jobs is an incipient phenomenon, emerging in substantial numbers since 2002 and growing rapidly. Kovac, Oldenski, and Sly (2018) also defined the term 'offshoring' as being used to describe a variety of distinct economic activities, from the hiring of workers by foreign affiliates of multinational enterprises, to hiring by foreign suppliers that sell inputs to domestic firms at arms-length, or more restrictively, offshoring sometimes describes the instance when a domestic plant is relocated abroad.

Although all these definitions of offshoring are similar, Hersh and Gurwitz (2014) provided a definition more focused on the offshoring of U.S. jobs. They stated that offshoring is "the practice of moving production to foreign locales while continuing to sell goods to the U.S. market". All these definitions of the term "Offshoring" are to some extent similar to each other.

In addition to the definitions of "offshoring", a few definitions of "supply chain management" have been provided as well. Hayes (2020) defined supply chain management (SCM) as "the management of the flow of goods and services and includes all processes that transform raw materials into finals products." $\mathrm{He}$ also mentioned that "Supply Chain Management involves the streamlining of a business's supply-side activities to maximize customer value and gain a competitive advantage in the marketplace." Mooney (2019) provided a similar definition by stated that supply chain management involved the flow of goods and services in an efficient manner. As she said, "It (SCM) encompasses all the steps involved in procuring raw materials through to the finished goods, in a way that is streamlined and provides value to the customer." These definitions of the term "Supply Chain Management" are similar.

Besides the definition of Supply Chain Management, Mooney (2019) also emphasized the importance of supply chain management. She said that supply chain management is a crucial part of the operations of any company as it establishes strong communication and relationships with suppliers, thereby helping to avoid shipment delays and diminish logistical errors. She further stated that efficient supply chain management gives companies better negotiating power to get the best rates and products in the shortest time possible, which reduces their inventory costs and improves the planning and efficiency of their operations.

There is a clear and obvious link between offshoring and the supply chain. Indeed, as explained above the supply chain involves all processes contributing to a company's provision of value to the customer by selling goods to them and offering them services matching their wants and/or needs. Offshoring involves a company's transfer of certain of their services to partners operating abroad. The performance of the services or jobs being offshored contributes to the offshoring or local company's operations and provision of value to their customers through the supply of goods and services to them. Therefore, offshoring impacts the supply chain by contributing to the provision of value to the offshoring or local company's customers through their purchases of goods and subscriptions to services. 


\section{REASONS FOR OFFSHORING}

The PRB (2008), Hersh and Gurwitz (2014), Kovac, Oldenski, and Sly (2018) identified various reasons for offshoring in general, and for the offshoring in the US in particular. Such reasons are reduced costs, the provision of better products and services to foreign markets, the growth of the market in emerging countries, government policies and incentives to engage in offshoring, technological changes and social norms, and shifts in employment relations and norms.

\section{Reduced Costs}

From a business perspective, it makes sense for the manager of a firm to offshore local jobs and services if the job performance of the domestic labor force is expensive as compared to that of foreign employees with similar skills. That is, if the foreign workers can perform the same services as the domestic ones at a significantly lower cost. Most firms which opt for offshoring do so to reduce the high costs that they would have incurred by producing or providing services using local employees. Offshoring also allows firms to benefit from the cost reductions available to them when they use foreign employees for the production of their goods or for provision of their services.

The PRB, illustrating the reduced costs of offshoring U.S. jobs, mentioned that firms use offshore jobs to reduce costs (2008). The PRB provided as example that a typical accountant in India earns about $\$ 5,000$ per year, whereas a U.S. accountant earns about $\$ 63,000$ and established that these large wage differentials make it very attractive for companies to lower costs by substituting U.S. workers with lower-cost overseas workers (2008). The PRB (2008) also quoted the CEO of a major technology company, saying "If you can find high quality talent at a third of the price, it's not too hard to see why you'd do this [send jobs offshore]." The PRB then concluded that by lowering costs through offshoring, firms can gain a business advantage over their competitors (2008).

Confirming what has been said above, Kovac, Oldenski, and Sly (2018) claimed that "a reduction in the cost of offshoring jobs or activities reduces the cost of production and induces firms to scale up their levels of production. The cost advantages afforded to these firms may induce job losses at competitors within domestic industries".

\section{The Provision of Better Products and Services to Foreign Markets}

This reason applies to firms providing products and offering services to foreign markets. For a multinational firm located in the U.S. providing products and offering services only to foreign markets or to both U.S. and foreign markets, hiring foreign employees (from the countries where it operates outside the U.S.) is a good idea due to their familiarity with the culture and customers' tastes in these countries. The PRB (2008), supporting this argument, suggested that "Companies selling to an overseas market sometimes find it easier to use local workers (from that overseas country) to customize a product because they better understand the tastes of the customers."

\section{Growth of the Market in Emerging Countries}

According to Hersh and Gurwitz (2014), "Market pressures drive businesses to seek reduced production costs, often in places where standards of living and protections for workers and the environment are more lax than in the United States." Their search for such reduced production costs is what leads them to offshore U.S. jobs. Besides, the PRB argued that the markets in many emerging countries with a burgeoning new consumer class, such as India and China, are growing at three to four times the rate of markets in developed countries in North America and Europe. As such, the growth of these markets encourages the offshoring of European and North American jobs (including U.S. jobs).

\section{Government Policies and Incentives to Engage in Offshoring}

Many governments also encourage the offshoring of jobs using policy making and various incentives. The PRB (2008) mentioned that governments are actively pursuing offshore outsourcing of U.S. and European jobs by offering an array of incentives, such as tax holidays (where the firm pays no income or 
property taxes), new facilities at reduced rates, and training subsidies. Moreover, it was also stated by the PRB that the U.S. government tax and immigration policies are actually speeding up offshoring (2008). In fact, the PRB established that U.S. based multinational corporations that outsource work offshore receive tax breaks. Offshore outsourcing firms have exploited loopholes in U.S. immigration policy, particularly in the H-1B and L-1 guest worker visas, to facilitate the transfer of work overseas.

Discussing the tax breaks received by firms which offshore some of their jobs and services, Kovac, Oldenski, and Sly (2018) argue that such tax breaks and the cost reductions provided as incentives for offshoring activities originate from Bilateral Tax Treaties made or signed by governments. They mentioned that "changes in the relative costs of offshore activity result from new bilateral tax treaties (BTTs). These treaties allow US firms to avoid double-taxation, in which the same income is taxed in two jurisdictions due to constraints on the size of the foreign tax credit available to parent firms. BTTs make this constraint less likely to bind, lowering the average effective tax rate on income from foreign affiliates, hence lowering the overall cost of offshore activity."

\section{Technological Changes and Social Norms}

Technology advances also permit and facilitate offshoring. As suggested by the PRB, "major changes in technology and social norms have enabled offshoring. Technological breakthroughs in telecommunications, the Internet, and collaborative software tools have dramatically lowered the costs of doing business remotely and across borders" (PRB, 2008).

\section{Shifts in Employment Relations and Norms}

In addition to technological changes, "shifts in employment relations and norms have made it much easier for firms to substitute foreign workers for U.S. workers." (PRB, 2008).

\section{IMPACT OF COVID-19 ON OFFSHORING AND ON THE SUPPLY CHAIN IN THE US}

This section of the paper provides the positive and negative effects of the Covid-19 pandemic on offshoring and on the supply chain in the US. The Covid-19 pandemic has had a negative impact on a lot of companies. However, it was also beneficial to some extent.

\section{Benefits}

The increase in the number of people remote working (or teleworking) provides an opportunity for companies' increased reliance on offshoring. Indeed, the number of people remote working (or teleworking) rose as a result of the pandemic. This made companies realize that "at least some of the jobs that are being performed remotely under Covid-19 are highly suitable for remote work" (Tan, 2020). But the increased reliance on remote work provides an opportunity for increased offshoring. As Tan (2020) states: "If you have decided that people can work from home, do they even need to be in the same country as the office?"

The rise of online commerce during the pandemic is expected to continue and will make supply chains more efficient. In fact, with many customers ordering online during and after the lockdown period, online sales (which were already high before Covid-19) increased tremendously. The online commerce growth is expected to continue even after the pandemic as argued by Greg Orr and Ken Bays in Arabe (2020).

Besides, the closure or reduced activity of many partner companies overseas during the Covid-19 pandemic makes a reduced reliance on offshoring by companies and increased rebuilding of networks and services locally by a lot of American companies possible. Rich Kerr stated in Arabe (2020) that: "Companies will reassess and rebuild their vendor network closer to the United States, pending the initial implementation phases of USMCA." As mentioned in Carter (2020), the offshore dependencies of banks and companies exposed them to operational risks due to the fact that "many offshore facilities were less prepared to address the Covid-19 operational challenges owing to a lack of opportunities for remote working or reduced availability of staff."

Covid-19 in the U.S. also highlighted the importance of truck drivers and delivery people. According to Greg Orr in Arabe (2020): "For truck drivers, COVID also has shined a bright and deserving spotlight 
on their role as essential to the economy for keeping store shelves filled. We are seeing more acts of kindness shown to our drivers, and more appreciation for the work they do every day." Covid-19 has also been validating for the companies that already had a high degree of automation and remote access to critical business applications as argued by Mahesh Rajasekharan in Arabe (2020).

Finally, the pandemic has significantly increased companies' adoption of innovative workforce management practices across the supply chain. Indeed, as expressed by Robert O'Dwyer "With workplace safety and employee engagement more critical than ever, modern systems are being leveraged to adapt production schedules and team design to promote social distancing; introduce new protocols for enterprise contact tracing using workforce management data; and provide flexibility to the frontline workforce, for instance, enabling them to manage schedules remotely or swap a shift via their mobile device." (Arabe, 2020).

\section{Drawbacks}

The Covid-19 pandemic made the supply chain vulnerable by revealing the increased need for digitization of the supply chain. As established by Larimer in Arabe (2020), "the pandemic uncovered vulnerabilities in the supply chains where paper-based processes and a lack of real-time information disrupted many. The need for further digitization of the supply chain became very apparent as a way to build more collaborative platforms with trading partners, suppliers, and customers."

Additionally, increased uncertainty caused by the Covid-19 pandemic made manufacturers and companies more cautious than ever in the procurement or purchase of their goods (products). In fact, in an effort to save funds during the pandemic, companies have changed their procurement and sales strategies. Their new strategies have been low-volume, high-frequency, and manufacturing-on-demand. An explanation provided by Jim Belosic in Arabe (2020) is that: "Instead of ordering 10,000 units and storing them, uncertainty in the market is causing manufacturers to order 1,000 units at a time with greater frequency."

Also, during Covid-19, the inability of companies which did not invest in resiliency to adapt to this new situation was revealed were exposed. As mentioned by John Mcpherson in Arabe (2020): "Companies that didn't invest in resiliency had no idea how exposed they were; they couldn't pivot because they were so locked into doing things the cheapest way possible."

Furthermore, the pandemic greatly disrupted the supply chains and the operations of several companies. Indeed, COVID-19 is to blame for massive disruptions to global and domestic supply chains as well as for unprecedented logistics challenges as argued by Chuck Cannata and Mark Goode in Arabe (2020). Cannata noted that "Trailer leasing has provided companies the flexibility and affordability to keep up with unpredictable surges in demand for essential goods as well as storage for backlog of non-essential inventory awaiting stores to reopen." (Arabe, 2020). Goode mentioned that "COVID-19 has exposed supply chains that are fragile to disruption due to the rigid solutions that support them. The companies that deploy agile solutions that ensure visibility and the control will be the winners now and post-pandemic." (Arabe, 2020).

\section{ADVANTAGES AND DISADVANTAGES OF OFFSHORING ON COMPANY SUPPLY CHAINS}

This segment of the paper will discuss the impact of offshoring on the supply chain of companies in general, and particularly in the US. The positive effects of offshoring will be presented as advantages or benefits. The negative effects of offshoring as well as the problems posed by offshoring will be presented as disadvantages or drawbacks. Offshoring has many benefits and disadvantages, some of which are presented below.

\section{Advantages of Offshoring}

Offshoring increases the firm's productivity and makes production more efficient because hiring foreign employees reduces production costs. According to Suzy Khimm (2012), "offshoring tends to increase productivity and reduce costs." Furthermore, Offshoring can have positive effects on the economy of the foreign countries where jobs, services or activities are offshored. 
The foreign employees getting jobs from American and other multinational firms through offshoring, spend their earnings from these jobs in their country, and therefore contribute positively to the economy of their country. Besides, the productivity and profits of multinational firms based in foreign countries, which are due to offshoring and to the location of their production in the U.S. or in other foreign countries, are invested in these foreign countries where these multinational firms are based, and therefore offshoring is good for the economy of these foreign countries.

Additionally, Offshoring contributes to the expansion of domestic jobs. Indeed, the reduced costs provided to the multinational firms based in the U.S. which offshore jobs and their increased productivity can lead these companies to expand domestic employment so as to hire more employees, which will offset or balance out the number of jobs lost due to offshoring. Doing so will nullify the negative effect of offshoring on domestic employment and ensure that it has a neutral impact on it.

According to Suzy Khimm (2012), the low costs provided to the firms offshoring jobs and services as well as the ensuing productivity of these firms can prompt or lead these firms to expand domestic employment hiring enough to offset the jobs lost to workers overseas. She quotes the authors of the research she analyzes as follows: "Offshoring has no effect on native employment in the aggregate. While offshore workers compete directly with natives, their employment generates productivity gains that 'increase the size of the pie,' leading to an overall neutral impact on native employment."

Besides, statistics by the Bureau of Labor Statistics as included in Fennell (2007) and Research by Mankiw and Swagel (2006 qtd. in Fennell, 2007) support the argument that the "negative" effect of offshoring on the US workforce (job level) is virtually insignificant as compared to the number of jobs created. A few years ago, Forrester Research estimated "that a cumulative total of 830,000 jobs would be moved offshore by the end of 2005, and that a total of 3.4 million additional US jobs would move overseas in the decade through the end of 2015" (Mankiw and Swagel, 2006 qtd. in Fennell, 2007). The Bureau of Labor Statistics estimated that 160 million US job positions were expected to be filled by 2015 (Fennell, 2007). The number is also put in perspective by the fact that there was a net increase of 35 million jobs over the last decade with even bigger swings in additions and deletions of jobs that produced the net 35 million (Mankiw and Swagel, 2006 qtd. in Fennell). This illustrates how small the number of jobs lost due to offshoring on the US job level is as compared to the number of jobs created.

Offshoring can also have positive effects on the U.S. economy. As contended by Brainard and Litan (2005), "Overall offshoring will offer economic gains." The productivity of U.S. based multinational firms that is due to offshoring and is used to expand local or domestic employment contributes positively to the economy as these local employees spend their earnings in the U.S.

Additionally, the productivity and profits of U.S. based multinational firms which are due to offshoring are invested in the U.S. and such investments affect positively the U.S. economy. Besides, other multinational firms based in foreign countries offshore jobs and locate their production in the U.S. for sale in other countries' markets, and this has positive effects on the economy as it provides employment to U.S. workers. Indeed, according to Hersh and Gurwitz (2014), "Multinational companies from other countries are locating production in the United States for sale in other countries' markets."

Furthermore, Fennell (2007) supporting the previous argument pointed out that moving jobs overseas creates jobs in the US. He stated that "rather than replacing or substituting domestic jobs, US firms' activity in foreign countries can actually complement their domestic activity."

Another benefit of offshoring is that the activities of the company where services are offshored complement the activities of the parent company as argued in Fennell (2007). A point supporting that argument was provided in Mankiw and Swagel (2006 qtd. in Fennell 2007). It was provided in Mankiw and Swagel (2006) that for every ten dollars of additional foreign employee compensation there was an addition of eighteen dollars into domestic employee compensation.

\section{Disadvantages of Offshoring}

Offshoring causes people to lose their jobs. In fact, offshoring some U.S. jobs means substituting or replacing U.S. employees who used to do these jobs by foreign employees who will do the same job at a lower cost. The U.S. employees who have lost their jobs due to offshoring become unemployed. As 
mentioned by Suzy Khimm (2012), in certain manufacturing industries, the native share of employment has "ambiguously" gone down, forcing workers who have lost their jobs to offshoring to look for work in another sector altogether. Brainard and Litan (2005) also stated that despite the economic gains provided by the Offshoring of U.S. jobs, it is costly to a portion of the workforce and to other entities as well because some American workers, companies, and possibly communities will lose out in the process.

An argument consistent with the previous argument is the one included in Fennell (2007) that offshoring has lowered the real wages of low skilled U.S. manufacturing workers. According to Marchant and Sanjeev (2005 qtd. in Fennell, 2007), one study found that two-thirds of those laid off because of offshoring earned less money upon reemployment, and almost $25 \%$ of them earned at least $30 \%$ less. The offshoring of U.S. jobs can have a negative effect on the U.S. economy because the American employees who have lost their jobs due to offshoring become unemployed, and as such cannot contribute positively to the U.S. economy.

The offshoring of jobs by other multinational firms based in foreign countries which locate their production in the U.S. for sale in other countries' markets has a negative effect on the economy in foreign countries because their employees get replaced by U.S. workers. According to Dessler (2015), "sending out jobs particularly overseas presents employers with special personnel challenges including the likelihood of cultural misunderstandings, security and information privacy concerns, the need to deal with foreign contracts, liability, legal system issues and the fact that the offshore employees need special training."With regards to the benefits and drawbacks of offshoring in general and of the offshoring of U.S. jobs in particular, various authors including Khimm (2012); and Kovac, Oldenski, and Sly (2018), Fennell (2007), Mankiw and Swagel (2006) concluded that the advantages of the offshoring, especially in the US (including reduced cost of production and increased productivity) outweigh its disadvantages and its "neutral" effect on domestic employment. They are right, but let's not forget that a portion of the American workforce, some American companies not involved in offshoring, and communities will suffer from unemployment, lower productivity as compared to competition and other problems due to the offshoring in the US, as argued by Brainard and Litan (2005).

Additionally, were all multinational firms based in the U.S. to relocate their production overseas through offshoring, the American economy would be seriously and negatively affected. These represent significant issues and the next part will provide recommendations to solve the disadvantages and problems posed by offshoring.

\section{RECOMMENDATIONS}

Considering the advantages (and especially the economic benefits) of offshoring for firms, individuals, and countries; most firms in the US and elsewhere should continue offshoring. However, considering the drawbacks of offshoring or the cost of offshoring to individuals, firms, and communities. Firms should not offshore their whole production jobs. They should make or produce some of their goods locally and use more the domestic or local labor force to do so. The following recommendations will allow them to do that.

- Governments and companies should have the desire to invest more in local communities.

- Governments should provide a quota of the number of jobs in each department (including production and manufacturing jobs) that may be offshored by each company, and of the number of jobs in each department that should be provided to the local labor force.

- Governments should keep providing incentives to firms which are offshoring some of their production jobs, but it should also provide incentives to companies attempting to reshore their operations (bring all their operations and services previously offshored back home), thereby encouraging them and other firms to reshore or bring back some of their production jobs at home.

According to Hersh and Gurwitz (2014), this could be done through policies like tax credits that reduce the costs companies incur when they reshore some production or manufacturing jobs back to the U.S., to local communities, or their home country. Following these recommendations will allow firms in the U.S. 
and other countries to keep benefitting from offshoring while minimizing the disadvantages of offshoring, or the problems posed by offshoring, to the local and foreign employees.

\section{CONCLUSION}

In conclusion, it is worth mentioning that offshoring and supply chain management are very important in operations management nowadays. There are many reasons leading companies in the US and in other countries to offshore some services and some parts of their operations, including the reduced cost and government incentives provided to such companies, the will to provide better products and services to foreign markets, the growth of markets in foreign emerging countries, the technological changes, and the shifts in employment relations and norms.

Offshoring has both positive and negative impacts on the supply chain of a company. Offshoring is beneficial to multinational firms based in the US, employees in the foreign countries in which jobs are offshored, employees in the US, the economy of the foreign countries themselves, and the US economy as it provides them with several advantages identified above. However, the offshoring of US jobs also has disadvantages for the US employees, the US economy, and the multinational firms based in the United States, foreign employees.

It is also worth mentioning that in response to the contention by the advocates of the adverse effects of offshoring in general and of offshoring in the US that offshoring causes US employees to lose their jobs, the proponents of the advantages of offshoring in general and of offshoring in the US argued that the offshoring of US jobs has, in the worst case scenario a neutral effect on domestic employees as it contributes to the expansion of domestic jobs and allows firms to use the profits from their increased productivity to hire enough local employees to offset the local jobs lost due to the original offshoring.

Considering the positive impact (benefits) of offshoring on companies' supply chains presented in this paper, firms in the US and in other countries should keep offshoring jobs or services and benefitting from the advantages that it provides. But these firms should offshore jobs or services differently, especially after taking the negative impact (drawbacks) of offshoring on companies' supply chains into account. The US government and US firms should have the desire to invest more in local communities and protect local jobs.

The US government should regulate offshoring by providing a quota of the number of jobs that may be offshored by US companies, and of the number of jobs in each department that should be provided to the local employees. The US government should foster firms' investment in local communities and in local employees by providing incentives such as tax credits to companies' reshoring jobs in the United States. Following these recommendations will allow firms in the US and in other countries to keep benefitting from offshoring, while minimizing the disadvantages of offshoring and the problems posed by offshoring to the employees in the United States and elsewhere.

\section{REFERENCES}

Arabe, K. (2020). What's the most significant way COVID-19 has changed the supply chain? Inbound Logistics. Retrieved November 19, 2020, from https://www.inboundlogistics.com/cms/article/whats-the-most-significant-way-covid-19-haschanged-the-supply-chain/

Brainard, L., \& Litan, R.E. (2005). Services Offshoring, American Jobs, and the Global Economy. Perspectives on Work, 8(2), 9-12. Retrieved November 15, 2020, from https://www.brookings.edu/wp-content/uploads/2016/06/2005winter_brainardlitan.pdf

Dessler, G. (2015). Human Resource Management (14th Edition). Pearson Education Ltd.

Elliot, M. (2018). American Companies Keep Sending Thousands of Jobs Overseas. Retrieved November 15, 2020, from https://www.cheatsheet.com/money-career/american-companies-sent-jobsoverseas.html/

Fennell, D.H. (2007). The Importance of Outsourcing and Offshoring in the United States. University of Tennessee Honors Thesis Projects. Retrieved November 19, 2020, from 
https://trace.tennessee.edu/cgi/viewcontent.cgi?referer=https:/www.google.com/\&httpsredir=1\& article $=2066 \&$ context $=$ utk_chanhonoproj.

Hayes, A. (2020). Supply Chain Management (SCM): What You Need to Know. Investopedia. Retrieved November 19, 2020, from https://www.investopedia.com/terms/s/scm.asp

Hersh, A., \& Gurwitz, E. (2014). Offshoring Work Is Taking a Toll on the U.S. Economy. Retrieved November 15, 2020, from

https://www.americanprogress.org/issues/economy/news/2014/07/30/94864/offshoring-work-istaking-a-toll-on-the-u-s-economy/

Khimm, S. (2012). Offshoring creates as many U.S. jobs as it kills, study says. The Washington Post. Retrieved November 15, 2020, from

https://www.washingtonpost.com/news/wonk/wp/2012/07/12/study-offshoring-creates-as-manyu-s-jobs-as-it-kills/?noredirect $=$ on\&utm_term $=.37 \mathrm{fdf} 67 \mathrm{f} 0052$

Kovak, B., Oldenski, L., \& Sly, N. (2018). The positive and negative effects of offshoring on domestic employment. Vox. Retrieved November 15, 2020, from https://voxeu.org/article/positive-andnegative-effects-offshoring-domestic-employment

Mankiw, N.G., \& Swagel, P. (2006). The Politics and Economics of Offshore Outsourcing. Journal of Monetary Economics, 53(5), 1-32.

Marchant, A.M., \& Sanjeev, K. (2005). An Overview of U.S. Foreign Direct Investment and Outsourcing. Review of Agricultural Economics, 27(3), 379-386.

Mooney, S. (2019). 5 Tips for Efficient Supply Chain Management. Inbound Logistics. Retrieved November 19, 2020, from https://www.inboundlogistics.com/cms/article/5-tips-for-an-efficientsupply-chain-management/

PRB. (2008). Offshoring U.S. Labor Increasing. Retrieved November 15, 2020, from https://www.prb.org/offshoring/

Reshoring Initiative. (2017). How Many Jobs Have Been Lost To Offshoring, And Can Be Recovered By Reshoring? Retrieved November 15, 2020, from http://reshorenow.org/blog/how-many-jobshave-been-lost-to-offshoring-and-can-be-recovered-by-reshoring/

Tan, P.E. (2020). Offshoring in the time of COVID-19-why and how companies can address it. OML Consulting. Retrieved November 19, 2020, from https://medium.com/@omlconsulting/offshoring-in-the-time-of-covid-19-why-and-howcompanies-can-address-it-14e2988d77da 